\title{
Submerged macrophyte vegetation and the European Water Framework Directive: assessment of status and trends in shallow, alkaline lakes in the Netherlands
}

\author{
H. Coops · F. C. M. Kerkum - M. S. van den Berg • \\ I. van Splunder
}

(C) Springer Science+Business Media B.V. 2007

\begin{abstract}
The submerged macrophyte vegetation of lakes created after enclosing former estuaries, situated in the central and southwestern part of the Netherlands, has been monitored annually from 1992 onwards. Between 1992 and 2004, pronounced changes in overall cover and species composition of the submerged vegetation have occurred, resulting from changes of water quality and morphology in the lakes. In most cases vegetation cover and species diversity increased or remained stable, with the exception of two lakes in the southwest part of the country. Abundance and species composition were assessed according to the requirements of the EU Water Framework Directive, using the assessment procedure proposed to assess macrophytes in natural water bodies in the Netherlands. The assessment procedure included calculation of the 'ecological quality ratio' (EQR) for each of eleven water bodies in each of 13 years, based on transect monitoring data. The EQR indicating
\end{abstract}

Guest editors: R. D. Gulati, E. Lammens, N. De Pauw \& E. Van Donk

Shallow lakes in a changing world

H. Coops $(\bowtie)$. F. C. M. Kerkum .

M. S. van den Berg . I. van Splunder

Institute for Inland Water Management and

Wastewater Treatment (RIZA), P.O. Box 17,

8200 AA Lelystad, The Netherlands

e-mail: hugo.coops@wldelft.nl
Good Ecological Status for Macrophytes was achieved in only three of the lakes. The consequences of hydromorphological modifications, and measures necessary to achieve the desired condition are discussed. Nutrient concentrations should be reduced further, while additional management measures are necessary to improve conditions for macrophytes.

Keywords Assessment - Biological monitoring · Submerged macrophytes · Water Framework Directive

\section{Introduction}

Macrophytic vegetation plays a key role in shallow lake ecosystems. Changed water quality due to increased nutrient levels has had a strong negative impact on the abundance and species composition of the aquatic vegetation in many lakes: various recent studies in Europe have shown severe reductions of submerged plants (e.g., Sand-Jensen et al., 2000; Körner, 2002) as well as emergents (e.g., Ostendorp, 1989; Graveland \& Coops, 1997). One of the priorities of lake restoration projects usually comprises the recovery of abundant macrophyte presence (Gulati \& Van Donk, 2002). Many efforts have already been made to restore lakes, and the European Water Framework Directive (WFD, European Commission, 2000), 
adopted by the EU member states, will support further efforts by setting standards for ecological status of water bodies within Europe. Its objective is to sustain and enhance aquatic environments within the European Community by achieving at least 'good' ecological status for all water bodies by 2015, referring to a scale ranging from 'high', 'good', 'moderate', 'poor' to 'bad'. One of the essential elements of the Directive is that it demands the monitoring and assessment of surface waters using specific ecological quality elements, instead of primarily relying on hydrochemical data. Following the Directive, ecological quality of lakes should be based on four groups: phytoplankton, macrophytes and phytobenthos, benthic invertebrate fauna and fish fauna. According to the WFD's formulation, assessment of macrophytes and phytobenthos should include 'taxonomic composition and abundance', to be assessed in the context of undisturbed reference conditions. Effective and accurate monitoring of status and trends in macrophyte cover and species composition should therefore be applied. New assessment methods for macrophytes, that take into account the requirements for the WFD, are now being developed in the EU member states (Schaumburg et al., 2004; Van der Molen, 2004).

In the Netherlands, a new national method for macrophyte assessment of water bodies has been proposed (Van der Molen, 2004), including a procedure to determine an ecological quality ratio (EQR) based on macrophyte abundance and composition, using mostly theoretically derived relationships (Van den Berg et al., 2003;
Van der Molen, 2004), since reference locations in the Netherlands are not available.

Existing monitoring data can be a starting point to develop 'WFD-proof' assessment procedures. The present study uses results from existing monitoring in 11 large shallow water bodies in the Netherlands (Table 1) managed by the National Water Authority to preliminary assess the proposed method.

\section{Methods}

\section{Water bodies}

Monitoring data from 11 different water bodies situated in the lower basins of the rivers Rhine (9), Meuse (1) and Scheldt (1) were used to assess the status of macrophyte abundance and composition from 1992 until 2004 (Table 1). The lower Rhine lakes are all situated in the IJsselmeer area, and were created during the 20th century as the result of damming off the inland sea and the embankment of large part of it. IJsselmeer proper was separated from the Markermeer by a dam in 1978. The other lakes in the Rhine area (Zwarte Meer, Ketelmeer, Veluwemeer, Wolderwijd, Eemmeer, Gooimeer) are so-called 'border lakes', situated in-between the old land and the polders. In the southwest of the Netherlands, the lakes Volkerakmeer and Zoommeer were formed after enclosure of part of the Oosterschelde estuary in 1987.

The lakes vary in size between 8 and $>1000 \mathrm{~km}^{2}$, and all have extensive shallow areas
Table 1 Water bodies studied and available macrophyte monitoring data

a incl. IJmeer

b incl. Drontermeer

c incl. Vossemeer

d incl. Nuldernauw

e incl. Nijkerkernauw

\begin{tabular}{|c|c|c|c|c|}
\hline $\begin{array}{l}\text { Lake/water } \\
\text { body }\end{array}$ & $\begin{array}{l}\text { River } \\
\text { basin }\end{array}$ & $\begin{array}{l}\text { Total area } \\
\left(\mathrm{km}^{2}\right)\end{array}$ & $\begin{array}{l}\text { Littoral area } \\
(<3 \mathrm{~m})\left(\mathrm{km}^{2}\right)\end{array}$ & $\begin{array}{l}\text { No. of plots (transects) } \\
\text { monitored annually }\end{array}$ \\
\hline IJsselmeer & Rhine & 1125 & 99.5 & $304(4)$ \\
\hline Markermeer $^{\mathrm{a}}$ & Rhine & 691 & 115.7 & $161(3)$ \\
\hline Volkerakmeer & Meuse & 48 & 18.1 & $190(6)$ \\
\hline Veluwemeer $^{\mathrm{b}}$ & Rhine & 37 & 32.4 & $221(5)$ \\
\hline Ketelmeer $^{\mathrm{c}}$ & Rhine & 34 & 15.6 & $145(4)$ \\
\hline Gooimeer & Rhine & 26 & 16.0 & $138(3)$ \\
\hline Wolderwijd $^{\mathrm{d}}$ & Rhine & 25 & 20.2 & $203(4)$ \\
\hline Zwarte Meer & Rhine & 18 & 14.8 & $188(3)$ \\
\hline Eemmeer $^{\mathrm{e}}$ & Rhine & 15 & 12.7 & $97(2)$ \\
\hline Gouwzee & Rhine & 12 & 11.8 & $171(2)$ \\
\hline Zoommeer & Scheldt & 8 & 3.2 & $40(4)$ \\
\hline
\end{tabular}


(water depth $<3 \mathrm{~m}$ ). They are alkaline and eutrophic, and sediments consist almost entirely of clay and sand of marine/riverine origin.

\section{Monitoring of submerged vegetation}

Annual transect monitoring started in 1992. Transects consist of 3 rows of plots, situated $100 \mathrm{~m}$ apart, and spanning the shallow-water zone perpendicular to the shoreline. Each plot was represented by a georeferenced location where vegetation characteristics were sampled every year in July. Sampling at each location was done by throwing a rake in five directions, and collecting the plant material for species identification. Projected cover (for total vegetation and individual species) for each plot was estimated visually using a 7-point scale. Additionally, water depth and Secchi depth were determined at every plot.

For each water body, total cover in the shallow zone was calculated as the average cover of two strata (0-1.50 and 1.51-3.00 m, respectively) weighted according to their area within the lake. Species' abundances were determined by combining species frequency and median cover value. Three abundance classes were distinguished: (1) rare; (2) occasionalfrequent; (3) abundant-dominant.

Trends in cover over the period 1992-2004 were tested non-parametrically (Spearman rank test, significant at $P<0.05$ ).

\section{Macrophyte-based EQR}

The WFD requires assessment of the abundance and composition of macrophytic vegetation of water bodies, and quantification relative to a type-specific reference condition. The EQR gives the quantitative ratio between current and reference condition. The proposed method to establish the EQR for shallow, alkaline lakes in the Netherlands (Van der Molen, 2004) includes a scale to express ecological status of macrophytes in shallow (parts of) lakes, that was developed based on different attributes: (1) Abundance of submerged macrophytes: includes the average cover in the entire photic zone. For alkaline lakes as in the Netherlands, the photic depth limit is between 2 and $5 \mathrm{~m}$ (Van den Berg et al., 2002), but for practical purposes the limit is set at $3 \mathrm{~m}$ here. (2) Shoreline vegetation cover: the total cover of emergent (wetland) vegetation in the periodically inundated marginal area of a lake. Due to the regulated water levels in Dutch lakes, and lack of reliable elevation data, this attribute was not included. (3) Species composition of macrophytes: based on the occurrence of characteristic aquatic and plant species, weighed according to their degree of indicativeness and species' abundance. (4) Composition of phytobenthos, determined from the presence of positive and negative indicator species. Due to lack of data we

Table 2 Scheme of assessement of macrophytes (Van der Molen 2004) used in this study

Step 1: Abundance of submerged macrophytes: \% cover in the parts of the lake where water depth is between 0 and $3 \mathrm{~m}$. $\mathrm{EQR}_{\text {abundance }}$ is calculated by linear interpolation between class boundaries (bad $0-1 \%$, poor $1-5 \%$, moderate $5-25 \%$, good $25-50 \%$, very good $50-65 \%$ and higher).

Step 2: Species presence: score of characteristic species according to abundance in the water body.

Category 1 (score: rare 1, occasional-frequent 3, abundant-dominant 4): Chara aspera, C. contraria, C. globularis, C. hispida, C. vulgaris, Nitella hyalina, N. mucronata, N. opaca, Nitellopsis obtusa.

Category 2 (score: rare 1, occasional-frequent 2, abundant-dominant 2): Callitriche platycarpa, Elodea canadensis, Fontinalis antipyretica, Hottonia palustris, Hydrocharis morsus-ranae, Myriophyllum spicatum, M. verticillatum, Najas marina, Nuphar lutea, Nymphaea alba, Nymphoides peltata, Persicaria amphibia, Potamogeton berchtoldii, P. compressus, $P$. crispus, $P$. lucens, $P$. mucronatus, $P$. nododsus, $P$. obtusifolius, $P$. pectinatus, $P$. perfoliatus, $P$. praelongus, $P$. pusillus, P. trichoides, $P$. $x$ zizii, Ranunculus aquatilis, R. circinatus, Stratiotes aloides, Utricularia vulgaris, Zannichellia palustris. Category 3 (score: rare 1, occasional-frequent 1, abundant-dominant 0): Ceratophyllum demersum, Elodea nuttallii, Lemna gibba, L. minor, L. trisulca, Spirodela polyrhiza.

$\mathrm{EQR}_{\text {species }}$ is calculated by linear interpolation between class boundaries (bad 0-5\% of maximum score, poor 5-10\%, moderate $10-20 \%$, good $20-40 \%$, very good $40-100 \%$ ).

Step 3: Calculation of EQR by averaging EQR abundance $_{\text {and }} \mathrm{EQR}_{\text {species. }}$ Assignment of ecological status: bad (0-0.2), poor $(0.2-0.4)$, moderate $(0.4-0.6)$, good $(0.6-0.8)$, very good $(0.8-1.0)$.

The ecological quality ratio (EQR) is a value between 0 and 1, encompassing 5 equal quality classes: bad 0-0.2, poor 0.2-0.4, moderate $0.4-0.6$, good 0.6-0.8, high 0.8-1.0 
did not include this attribute. For this study the macrophyte EQR was calculated according to Table 2.

\section{Abiotic lake data}

Water quality data were obtained from the Dutch national water quality database. Monitoring stations were selected that are located centrally in each of the water bodies and had been sampled at least once per month in the period 1992-2004. We calculated summer-averaged (April-September) values of total phosphorus (TP), total nitrogen (TN) and chlorophyll- $a$.

\section{Results}

Individual lakes showed considerable variations in cover by macrophytes in the shallow-water zone (Fig. 1). Of the 11 lakes, Veluwemeer $(S=0.742, \quad P<0.005)$, Wolderwijd $(S=0.907$, $P<0.001)$, Eemmeer $(S=0.596, P<0.05)$, and Gouwzee $(S=0.790, \quad P<0.005)$ showed an increasing trend in cover, whereas Volkerakmeer $(S=-0.773, \quad P<0.01)$ and Zoommeer $(S=-0.709, P<0.05)$ showed a decreasing trend. Cover values in lakes were calculated using the surface areas of the two depth zones, viz. very shallow (0-1.5 m) and moderately shallow $(1.5-3 \mathrm{~m})$. The ratio between very shallow and moderately shallow areas ranged between 0.06 (Markermeer) and 4.1 (Zwarte Meer), having a distinct effect on the colonised part of the 0-3 m zone. The very shallow zone can be colonised by macrophytes even under relatively unsuitable conditions, while the less shallow area may only be colonised when underwater light conditions have improved (Fig. 2).

The total number of submerged macrophyte species observed in a single lake ranged between 5 and 19. A number of species were specifically occurring in one or two lakes only, such as Potamogeton nodosus (Ketelmeer) and Callitriche truncata (Volkerakmeer, Zoommeer). Of the more common species, most species showed an overall increase, such as Chara spp. (occurrence in all samples $18 \%$ in the first 6 years, $33 \%$ in the last 6 years), Potamogeton pectinatus (from $27 \%$

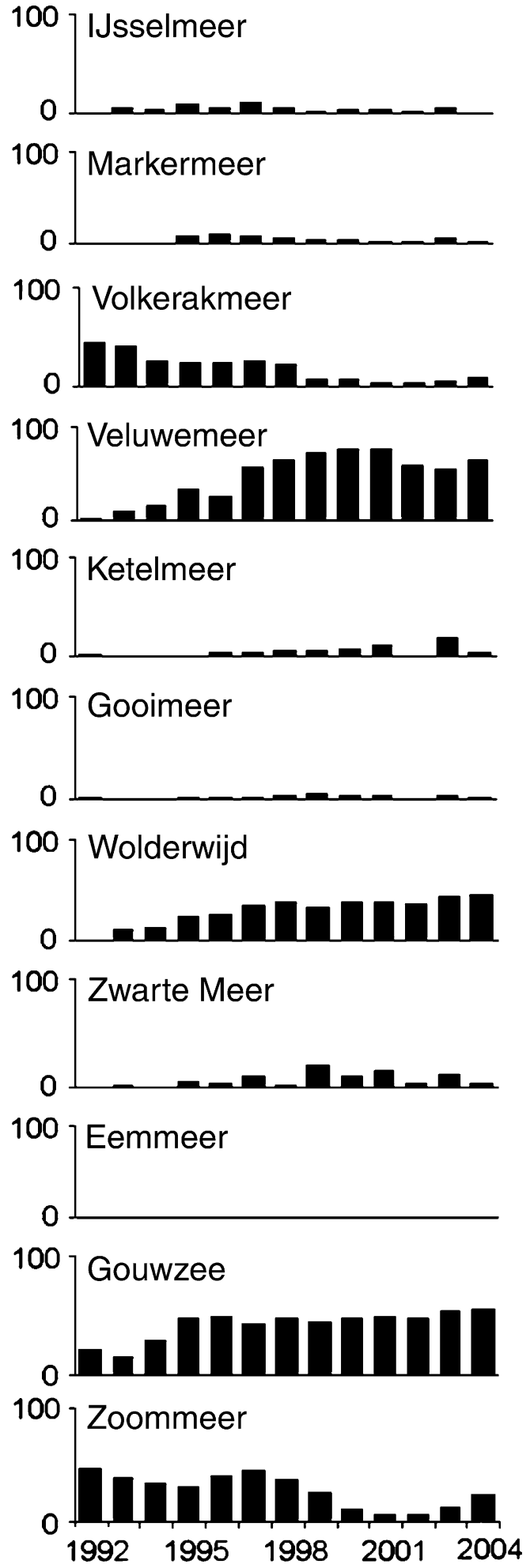

Fig. 1 Development of submerged vegetation cover $\%$ in shallow areas (water depth $<3 \mathrm{~m}$ ) in 11 lakes in The Netherlands between 1992 and 2004 
to $36 \%$ ), P. pusillus (from $17 \%$ to $21 \%$ ), and Zannichellia palustris (from 13\% to 29\%); whereas Myriophyllum spicatum decreased from $6 \%$ to $4 \%$. For individual lake-years, the species richness was positively correlated with the cover percentage in the $0-3 \mathrm{~m}$ zone (Pearson's $R=0.480, P<0.01)$.

Figure 3 shows that a submerged vegetation cover $>20 \%$ never occurred when summer-averaged TP-concentrations were above $0.15 \mathrm{mg} \mathrm{P} \mathrm{l}^{-1}$ (average cover $6 \pm 10 \%$ ). Similarly, cover was always higher than $20 \%$ with TP-concentrations below $0.08 \mathrm{mg} \mathrm{P} \mathrm{l}^{-1}$ (average cover $43 \pm 22 \%$ ). In the intermediate area, a wide variation of cover values was observed (average cover $18 \pm 17 \%$ ). For $\mathrm{TN}$, the relationship was much less clear, as high as well as low submerged vegetation cover occurred over the entire range of $1-7 \mathrm{mg} \mathrm{N}^{-1}$. High vegetation cover was limited by chlorophyll$a$, as submerged vegetation cover was always below $20 \%$ when average summer concentrations of chlorophyll- $a$ exceeded $50 \mu \mathrm{g} \mathrm{l}^{-1}$.

Calculation of EQR of the lakes showed that in most cases, the thresholds for Good Ecological Status were not met (Table 3). The 'good' status (overall EQR > 0.6) was achieved only in Veluwemeer (1995 and later years), Wolderwijd (1997 and later years) and Gouwzee (2003 and 2004). In 2004 the lakes Zwarte Meer, Volkerak-

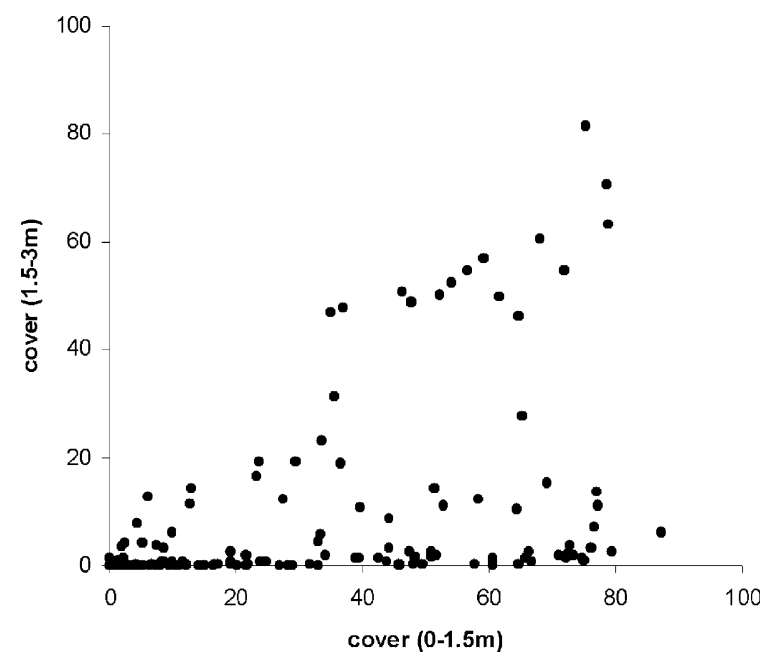

Fig. 2 Relationship between macrophyte cover in two water-depth strata $(0-1.5 \mathrm{~m}$ vs. $1.5-3.0 \mathrm{~m})$ based on data from 11 lakes in the period 1992-2004 meer and Zoommeer were classified as 'moderate', while IJsselmeer, Markermeer, and Ketelmeer were classified as 'poor', and Eemmeer and Gooimeer were classified 'bad' status for macrophytes. Obviously, nutrient loads are still too high in most cases to achieve the Good Status. Figure 4 shows that for lakes that reach Good status, the 95\% interval for TP is 0.04 $0.12 \mathrm{mg} \mathrm{l}^{-1}$, whereas for non-qualifying lakes, the $95 \%$-interval for TP is $0.07-0.34 \mathrm{mg} \mathrm{l}^{-1}$. Unnatural water levels, littoral morphology, inter-lake connectivity and fish populations may additionally suppress the good state for macrophytes in these lakes.

\section{Discussion}

The abundance and composition of aquatic vegetation may reflect the ecological status of shallow lakes. The response of macrophytes to the major environmental pressure of eutrophication has been demonstrated in various studies (SandJensen et al., 2000; Bachmann et al., 2002; Körner, 2002; Lauridsen et al., 2003), including the 'border lakes' that were among the lakes in the present study (Scheffer et al., 1992; Coops \& Doef, 1993). Shifts between high and low macrophyte cover may be discerned, related to certain

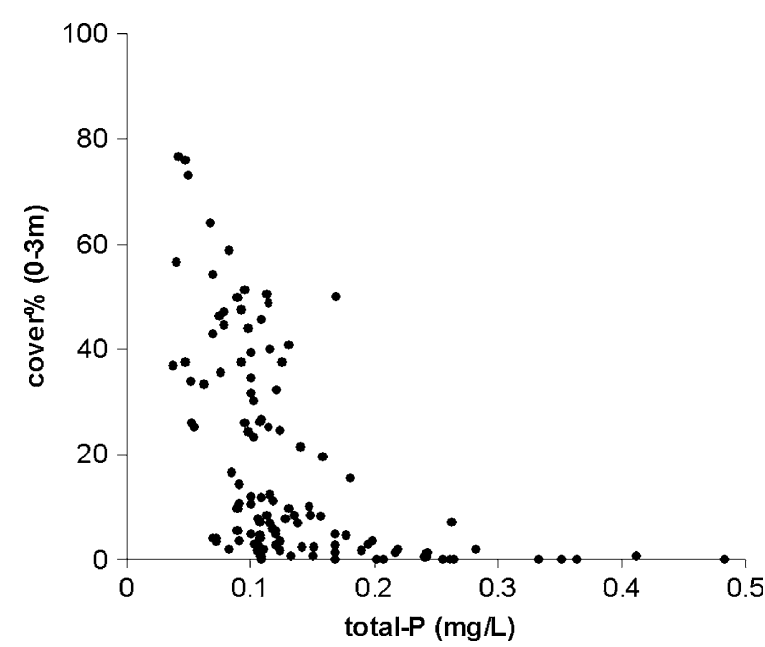

Fig. 3 Relationship between percentage cover by submerged vegetation in the shallow zone $(0-3 \mathrm{~m})$ and summer average TP concentration 
Table 3 Macrophyte cover and species richness of the lakes in 2004, and the EQR for abundance and species composition, as well as overall EQR for macrophytes

\begin{tabular}{lllcll}
\hline $\begin{array}{l}\text { Lake/water } \\
\text { body }\end{array}$ & $\begin{array}{l}\text { Cover of shallow area } \\
(\%)\end{array}$ & $\begin{array}{l}\text { Abundance } \\
\text { EQR }\end{array}$ & $\begin{array}{l}\text { Species richness } \\
(n)\end{array}$ & $\begin{array}{l}\text { Species composition } \\
\text { EQR }\end{array}$ & $\begin{array}{l}\text { Overall macrophyte } \\
\text { EQR }\end{array}$ \\
\hline IJsselmeer & 0.5 & 0.09 & 8 & 0.37 & 0.23 \\
Markermeer & 4 & 0.35 & 6 & 0.44 & 0.40 \\
Volkerakmeer & 9 & 0.44 & 8 & 0.40 & 0.42 \\
Veluwemeer & 65 & 1.00 & 16 & 0.64 & 0.82 \\
Ketelmeer & 4 & 0.34 & 7 & 0.37 & 0.36 \\
Gooimeer & 3 & 0.14 & 4 & 0.26 & 0.15 \\
Wolderwijd & 52 & 0.75 & 12 & 0.63 & 0.69 \\
Zwarte Meer & 3 & 0.30 & 14 & 0.55 & 0.43 \\
Eemmeer & 2 & 0.02 & 5 & 0.22 & 0.12 \\
Gouwzee & 57 & 0.85 & 8 & 0.48 & 0.66 \\
Zoommeer & 23 & 0.58 & 7 & 0.37 & 0.48 \\
\hline
\end{tabular}

thresholds in nutrient loading in lakes. Declines, respectively expansions of macrophyte cover tend to show sudden shifts between the clear, macrophyte-rich state, and the turbid, macrophyte-poor state of lakes (Scheffer, 1998). In some cases, these shifts have been attributed to catastrophic events, such as summer drawdown or ice scouring (Blindow, 1992). However, expansion of submerged vegetation seemed to occur gradually over a number of subsequent years in the recovering lakes in the Netherlands (Veluwemeer, Wolderwijd, Gouwzee). Likewise, the decreasing trend in Volkerakmeer and Zoommeer did not appear to occur as a sudden collapse of the vegetation, but rather as a gradual decrease. It

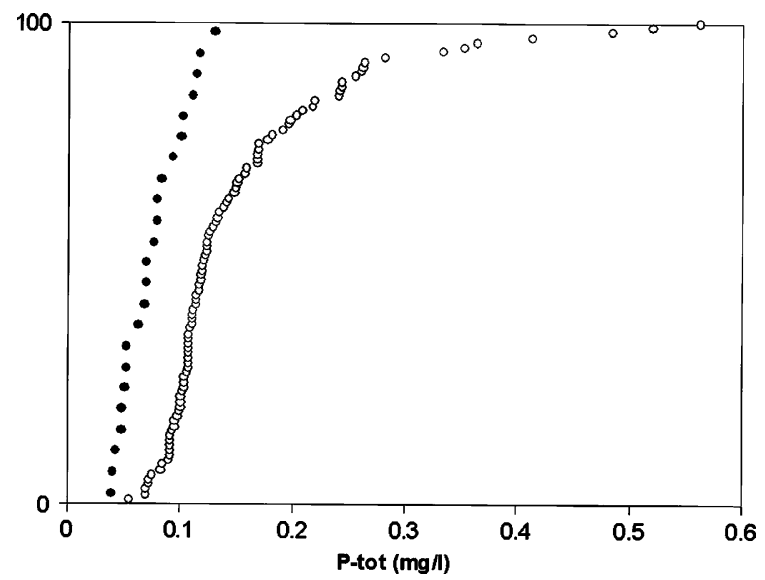

Fig. 4 Cumulative distribution of TP (average TP vs. \% of lake-years) fulfilling the good ecological state for macrophytes (black circles) and lake years not fulfilling the good ecological state for macrophytes (open circles) might be that the size of these lakes is so large that they do not respond uniformly, as if different sub-systems exist responding to different nutrient levels, morphometry, sediment type, etc. In Veluwemeer, macrophytes started to colonise the shallowest parts of the lake and expanded from there; a clear distinction between a clear- and a turbid area within the lake was observed related to the macrophyte-colonised area (Scheffer et al., 1994), until the entire lake became clear when $>60 \%$ was covered by submerged vegetation. The expansion of vegetation in a recovering lake depends on underwater light conditions in combination with morphometry (Duarte \& Kalff, 1986). Van den Berg et al. (2003) showed the high predictive value of water depth, exposure and transparency in modelling macrophyte dynamics in the 'border-lake' area.

Once a more or less dense cover of macrophyte vegetation has developed, this itself may affect nutrient cycling within lakes (Granéli \& Solander, 1988) and enhance and stabilise the clear water state in lakes (Portielje \& Van der Molen, 1999). Consequently, aquatic vegetation monitoring may be a suitable tool for evaluating the success of lake restoration management by reducing nutrient loading and naturalising hydromorphology (Melzer, 1999).

The observed interannual variation in abundance and, to a lesser extent, species composition of aquatic macrophytes can be attributed to several factors. Firstly, variation in sampling conditions and timing resulting in inaccurate or unrepresentative sampling cannot be ruled out to at least 
partly explain the large fluctuations in macrophyte cover. In addition, there may be sampling problems due to identification errors and observers' bias in cover estimations (Kercher et al., 2003). Shortterm seasonal changes in macrophyte abundance may be related to e.g., changes in water level, periphyton development, phytoplankton blooms, or herbivory. However, even with these uncertainties, year-to-year variations in macrophyte cover of lakes after recolonisation may be extremely large; for instance, Lauridsen et al. (2003) observed cover values fluctuating between 2 and $80 \%$ in restored Danish lakes. Despite this, our data showed clear trends for some lakes.

Macrophyte abundance is a quality element in the assessment of lakes according to the WFD and it particularly indicates the degree of eutrophication in lakes. Depth-limitation due to poor light conditions is reflected in the area covered, and can be related to the area that would be covered in reference, non-eutrophied conditions. In the case of Dutch alkaline, shallow lakes, the maximum colonisable depth for macrophytes was derived using empirical relationships between phosphorus, chlorophyll- $a$ and transparency, as well as minimum light requirements for dense macrophyte growth (Middelboe \& Markager, 1997; Van den Berg et al., 2002). The average cover of the area within this depth contour was used to determine the EQR for macrophyte abundance (Van der Molen, 2004), using limits for the quality classes 'high', 'good', 'moderate', 'poor' and 'bad' that were based on expert agreement. The class limits of the EQR for macrophyte composition, analogously, depend on expert agreement, as it is calculated by referring to a weighted presence of so-called characteristic species, that are based on species described for water-type specific plant communities (Van der Molen, 2004). The procedure reflects the lack of 'real' data that can be used to define the highest ecological status (the reference) and to derive the EQR from it. In other EU countries where reference sites have been available, the latter approach was often followed (Meilinger et al., 2005; Schaumburg et al., 2004; Stelzer et al., 2005).

The vast majority of lakes in the Netherlands have been classified as 'heavily modified', because of their altered hydromorphology and/or artificial origin. Hence the status relative to 'maximum ecological potential' rather than reference should be assessed. Because water levels are commonly regulated and shorelines are often artificial, we (tentatively) excluded incorporation of an EQR for emergent vegetation and marginal wetlands. Their assessment would require knowledge of the maximum potential for each individual water body. It is not clear yet whether, and how, this component will be included in the WFD macrophyte assessment. We also excluded the phytobenthos EQR, because of the lack of monitoring data and insufficient understanding of its relationships with pressures.

The present assessment of macrophyte quality in the 10 lakes of this study reflects very well the perceptions of various experts working in these lakes and the degree of recovery from the eutrophied conditions that were prevalent in the 1970's and 1980's. It can be concluded that currently most of the lakes are not in the good ecological state that should be achieved in 2015 . Measures that can be taken to improve the condition include a further reduction of nutrient loading. As efforts to reduce nutrient loadings further may prove increasingly difficult and costly, other measures that effectively improve transparency (e.g., biomanipulation) and morphometry, should be considered as well.

\section{References}

Bachmann, R. W., C. A. Horsburgh, M. V. Hoyer, L.K. Mataraza \& D. E. Canfield Jr, 2002. Relations between trophic state indicators and plant biomass in Florida lakes. Hydrobiologia 470: 219-234.

Blindow, I., 1992. Long- and short-term dynamics of submetrged macrophytes in two shallow eutrophic lakes. Freshwater Biology 28: 15-27.

Coops, H. \& R. W. Doef, 1993. Submerged vegetation development in two shallow, eutrophic lakes. Hydrobiologia 340: 115-120.

Duarte, C. M. \& J. Kalff, 1986. Littoral slope as a predictor of the maximum biomass of submerged macrophyte communities. Limnology and Oceanography 31: 1072 1080 .

European Commission, 2000. Directive 2000/06/EC of the European Parliament and of the Council of Europe (2000). Establishing a Framework for Community Action in the Field of Water Policy. Official Journal 
of the European Communities 22.12.2000:L327/IL327/72.

Granéli, W. \& D. Solander, 1988. Influence of aquatic macrophytes on phosphorus cycling in lakes. Hydrobiologia 170: 245-266.

Graveland, J. \& H. Coops, 1997. Verdwijnen van rietgordels in Nederland. Landschap 14: 67-86.

Gulati, R. D. \& E. Van Donk, 2002. Lakes in the Netherlands, their origin, eutrophication and restoration: state-of-the-art review. Hydrobiologia 478: 73106.

Kercher, S. M., C. B. Frieswyk \& J. B. Zedler, 2003. Effects of sampling teams and estimation methods on the assessment of plant cover. Journal of Vegetation Science 14: 899-906.

Körner, S., 2002. Loss of submerged macrophytes in shallow lakes in north-eastern Germany. International Review of Hydrobiology 87: 375-384.

Lauridsen, T. L., J. P. Jensen, E. Jeppesen \& M. Søndergaard, 2003. Response of submerged macrophytes in Danish lakes to nutrient loading reductions and biomanipulation. Hydrobiologia 506-509: 641-649.

Meilinger, P., S. Schneider \& A. Melzer, 2005. The reference index method for the macrophyte-based assessment of rivers-a contribution to the implementation of the European Water Framework Directive in Germany. International Review of Hydrobiology 90: 322-342.

Melzer, A., 1999. Aquatic macrophytes as tools for lake management. Hydrobiologia 395/396: 181-190.

Middelboe, A. L. \& S. Markager, 1997. Depth limits and minimum light requirements of freshwater macrophytes. Freshwater Biology 37: 553-568.

Ostendorp, W., 1989. 'Die-back' of reeds in Europe-a critical review of literature. Aquatic Botany 35: 5-26.

Portielje, R. \& D. T. Van der Molen, 1999. Relationships between eutrophication variables: from nutrient loading to transparency. Hydrobiologia 409: 375-387.
Sand-Jensen, K., T. Riis, O. Vestergaard \& S. E. Larsen, 2000. Macrophyte decline in Danish lakes and streams over the past 100 years. Journal of Ecology 88: 1030-1040.

Schaumburg, J., C. Schwarz, G. Hofmann, D. Stelzer, S. Schneider \& U. Schmedtje, 2004. Macrophytes and phytobenthos as indicators of ecological status in German lakes-a contribution to the implementation of the Water Framework Directive. Limnologica 34: 302-314.

Scheffer, M., 1998. Ecology of Shallow Lakes. Chapman \& Hall, London, $357 \mathrm{pp}$.

Scheffer, M., M. R. De Redelijkheid \& F. Noppert, 1992. Distribution and dynamics of submerged vegetation in a chain of shallow eutrophic lakes. Aquatic Botany 42: 199-216.

Scheffer, M., M. S. Van den Berg, A. W. Breukelaar, C. Breukers, H. Coops, R. W. Doef \& M. L. Meijer, 1994. Vegetated areas with clear water in turbid shallow lakes. Aquatic Botany 49: 193-196.

Stelzer, D., S. Schneider \& A. Melzer, 2005. Macrophytebased assessment of lakes-a contribution to the implementation of the European Water Framework Directive in Germany. International Review of Hydrobiology 90: 223-237.

Van den Berg, M. S., W. Joosse \& H. Coops, 2003. A statistical model predicting the occurrence and dynamics of submerged macrophytes in shallow lakes in the Netherlands. Hydrobiologia 506-509: 611-623.

Van den Berg, M. S., D. T. Van der Molen \& P. C. M. Boers, 2002. Setting up reference conditions for phytoplankton, turbidity and submerged macrophytes in Dutch lakes. TemaNord 566: 28-31.

Van der Molen, D. T. (ed.), 2004. Referenties en conceptmaatlatten voor meren voor de Kaderrichtlijn Water. STOWA Report 2004-42, Utrecht, 450 pp. 